\title{
Evaluation of Oyster Mushroom (Pleurotus ostreatus) Cultivation Using Different Organic Substrates
}

\author{
Aisha M. Elattar ${ }^{1}$, Shimaa M. Hassan ${ }^{* 2}$ and Sherin F. A. Awd-Allah ${ }^{3}$
}

\begin{abstract}
Mushrooms can be considered as functional foods that can provide health benefits beyond the conventional supplements they contain. In the current study, oyster mushroom was grown using various agricultural wastes, including wheat straw (WS), rice straw (RS), saw dust (SD) and water hyacinth (WH), either single or mixed with wheat straw (RS+WS, SD+WS and WH+WS) at a ratio of 1:1 (w/w), in order to determine their significance on growth, composition and consumer acceptance. The experiments were conducted during the winter season (September to December and January to April) 2017/2018 at Agricultural Research Center, El-Sabahia, Alexandria governorate, Egypt. The results revealed that, combinations of (RS+WS) and RS alone produced the highest mushroom yield from the harvesting periods $\mathbf{( 7 6 0 0}$ $\mathrm{g}$ and $6650 \mathrm{~g}$, respectively). For freeze-dried powder, both chemical and nutritional values were examined, comparing between treatments mentioned above. The product grown on a mixture of (RS+WS) had the highest yield score. It showed to be a rich source of protein, minerals and fibres. It could be approved that oyster mushroom developed on blend of RS and WS is nutritious as well as a rich source in natural-pharmaceutical-type products. In this study, an attempt to recognize the alternative or mixture of substrates from various agricultural wastes and to evaluate the yield and quality of oyster mushroom (Pleurotus ostreatus) were studied. Using the best mushroom extract as prebiotic in fermented dairy products is recommended as trend that could contribute to innovative functional foods.
\end{abstract}

Key words: Agriculture wastes, biochemical tests, oyster mushroom (Pleurotus ostreatus), yield.

\section{INTRODUCTION}

Oyster mushrooms have a delicate surface and taste. The majority of consumable mushrooms may have the most shading decent variety: white, yellow, pink, dim, dark colored, and dark clam mushrooms (Pleurotus ostreatus) are normal and common development. The particular flavor or clam mushrooms make them a wonderful backup for fish and shellfish, despite the fact that they combine well with various meats such as chicken.

Fresh fruiting bodies of oyster mushroom show high moisture content (90 \%), where both dry and fresh oyster mushrooms are rich in carbohydrates $(57.6 \%)$, protein $(29.2 \%)$, fat $(2.1 \%)$, fibre $(8.2 \%)$ and ash $(9.8$ $\%)$. Therefore, oyster mushroom is a consumable mushroom; it contains sufficient measure of phosphorous, iron, protein, lipid, riboflavin and thiamine, also known as the meat of the veggie lover (Khan et al., 1981). Mushroom proteins are considered to be moderate between vegetable and animal proteins. The essential amino acids of the human body are found in the oyster mushroom (Kaushlesh et al., 2012). Pleurotus ostreatus contains numerous basic amino acids such as methionine, isoleucine, lysine and glutamic acids. It is also rich in physiologically meaningful primary and secondary metabolites and chemical elements. One hundred $\mathrm{g}$ of fresh fruiting bodies contain $15 \%$ of vitamin C's recommended daily intake, $40 \%$ of niacin, riboflavin, and thiamin, and 0.5 $\mathrm{mg}$ of vitamin B12. This species also has a high oleic acid content (40\%), linolenic acid (55\%) (Piska et al., 2017). The minerals, for example, ferrous sulfate, phosphorus, sodium and calcium are available in oyster mushroom (Pandey and Ghosh, 1996). It is used for food as well as medicine. Mushrooms have a high dietary advantage and a sparkling taste. Weight control plans are reasonable due to their low caloric value. Pleurotus ostreatus produces medicinal and pharmacological metabolites of antimicrobial, immunostimulant, antioxidant and antitumor interest (Elmastas et al., 2007).

Source of substrate, spawn quality, strain and compost affect the execution and development of oyster mushrooms (Royse et al., 2004). The genus Pleurotus is notable for the transformation of substrates into

DOI: 10.21608/asejaiqjsae.2019.49370

${ }^{1}$ Laboratory of Microbial Biochemistry of Dairy Microorganisms,

Department of Dairy Science and Technology, Faculty of Agriculture,

Alexandria University, Alexandria, Egypt

${ }^{2 *}$ Horticulture Science. Faculty of Agriculture, vegetable crops, Alexandria University.

Alexandria, Egypt.

${ }^{3}$ Nematology Research Department, Plant Pathology Institute,

Agricultural Research Center, Giza, Egypt.

Corresponding author: Shimaa Hassan

shimaahassan194@yahoo.com

Received August 13, 2019, Accepted September 12, 2019 
mushrooms. In Egypt, agricultural wastes are about 35 million tons between plant and animal residues. The utilized waste is about 7 million tons for feed and 4 million tons for organic fertilizer but 12 million tons of plant wastes are still useless (The Ministry of Environment report - Egypt 2014). The recycling of this waste leads to reduce rates of emerging environmental pollution from the burning of plant residues and escalating carbon dioxide and other gases causing global warming high temperature. It leads to increase the high temperature on the surface of the earth and emergence of the black cloud. Also, using of agricultural wastes in the production of mushroom leads to cut the life cycle of many insects, as well as resistance to rodents and rats which found during rice straw storage. Water hyacinth is one of the environmental pollutants as it spreads in the Nile River. It consumes high amounts of water in addition to absorb large amounts of soluble oxygen in the water, leading to many risks to the environment. Many researchers have shown that Pleurotus can be effectively developed on practically all farming squanders. Wheat, rice, maize, sugarcane bagasse and sorghum straw supported the great development of the mushroom and the rapid growth of mycelia. The structure of the substrates is also important because it helps to penetrate mycelium.

Therefore, the objective of the present study is to evaluate yield and nutritional composition of Pleurotus ostreatus which grown on the different organic agriculture wastes to select the suitable substrates for the production of the better mushroom quality and the best economic and environmental conditions to produce high quantity of oyster mushroom. This will allow the people at poor villages to produce high quality and quantity of mushroom with low production cost which will increase their income.

\section{MATERIALS AND METHODS}

The experiments were conducted during the winter season (September to December and January to April) of 2017/ 2018 at Agricultural Research Center, ElSabahia, Alexandria governorate, Egypt.

\section{Oyster mushroom cultivation}

\section{Substrate preparation}

Agricultural wastes including wheat straw (WS), rice straw (RS), saw dust (SD) and water hyacinth $(\mathrm{WH})$, either single or mixed with wheat straw (RS+WS, SD+WS and $\mathrm{WH}+\mathrm{WS}$ ) were evaluated to determine their effect on mass production and composition of oyster mushroom (Pleurotus ostreatus (Jacq.) P. Kumm). The ratio of each agro-waste and wheat straw was 1: 1 (WS: agro-waste, w/w).

\section{Inoculation, incubation, and culture conditions}

The agro-wastes or their mixture (WS, RS, SD, WH, $\mathrm{RS}+\mathrm{WS}, \mathrm{SD}+\mathrm{WS}$ and $\mathrm{WH}+\mathrm{WS}$ ) were immersed in water for 1-2 h, then washed 2 or multiple times in clean water to adjust the moisture content to $65 \%$, and $\mathrm{CaCO}_{3}$ was mixed at $0.2 \%$ of the mixture $(\mathrm{w} / \mathrm{w})$. Substrates were filled into polyethylene packs and sterilized at $121^{\circ} \mathrm{C}$ for $80 \mathrm{~min}$. After the substrates were chilled off to room temperature, they were inoculated with oyster mushroom spawning at a rate of 5\% of the substrates wet weight. The autoclaved substrates and spawn's mixtures were placed in three layers $(50 \mathrm{~g}$ of spawn in each layer), bottom, middle and surface of the substrate when the mixtures were filled into polyethylene packs. In this experiment using Completely Randomized Design (CRD) with three replicates, two duplicate polyethylene packs for the same substrate have been used for each replicate During the first three weeks, the inoculated bags were then placed under 80-95\% relative humidity with complete darkness in a spawn running room at $20-25^{\circ} \mathrm{C}$ until the substrates were fully colonized with mycelium. To encourage primordial starting, packs were punctured (shape) using a foursided clean knife. The runtime generated was recorded to add up to the substrate's mycelium colonization (Oei and van Nieuwenhuijzen, 2005).

\section{Harvesting and parameters}

When the tops developed completely and the fruiting bodies began to curl up, mushrooms were collected from the substrate. The mushroom clusters were weighed and several parameters were evaluated: first initiation; (time between the day of inoculation and the day of mycelium appearance), earliness harvest; (time between the day of inoculation and the day of first gathering) and biological efficiency (percentage yield of fresh mushroom over the substrate's dry weight) (Yang et al., 2013).

\section{Preparation of dehydrated mushroom powder (DMP)}

After cutting fresh mushrooms into $2 \mathrm{~mm}$ thick slices, they spread over aluminum trays in a single layer and kept overnight at $-80^{\circ} \mathrm{C}$, then subjected to freezedryer Zirbus (Vaco-5-11 Germany). The freeze dryer was programmed to operate primary drying cycle for $20 \mathrm{~h}$ at $0^{\circ} \mathrm{C}$ shelf temperature and 0.6 mbar chamber pressure, followed by secondary drying cycle at $15^{\circ} \mathrm{C}$ shelf temperature for $2 \mathrm{~h}$ and 0.4-0.5 mbar chamber pressure. The freeze-dried mushroom was electrically grounded to obtain dehydrated mushroom powder (DMP). The dehydrated mushroom powder was packed, sealed in plastic bags under vacuum and stored in a refrigerator $\left(4^{\circ} \mathrm{C}\right)$ until used. 


\section{Chemical composition of oyster mushroom.}

The dehydrated mushroom powder (DMP) samples have been chemically analyzed for dry matter (DM; AOAC 2006, ID number 930.15), organic matter (OM; ID number 942.05) and crude protein (CP; as 6.25 below N; ID number 954.01). ANKOM 220 Fiber Analyzer unit (ANKOM Technology Corporation, Macedon, NY, USA) was used to analyze neutral detergent fiber (NDF), crude fiber in addition to acid detergent fiber (ADF) according to Van Soest et al. (1991). Lignin (sa) content was sequentially determined in the same sample by solubilizing ADF with $720 \mathrm{~mL} /$ L sulfuric acid (Robertson and Van Soest, 1981). Hemicellulose, cellulose, total available carbohydrate and energy were calculated as mentioned below:

Hemicellulose $=\mathrm{NDF}+\mathrm{ADF}$

NDF: Neutral detergent fiber, ADF: Acid detergent fiber.

Cellulose $=\mathrm{ADF}-$ lignin

Total available carbohydrate $(\%)=[100-($ moisture + total ash + fiber + protein + fat $)]$

Energy $(\mathrm{kcal} / 100 \mathrm{~g})=[($ protein $\times 4)+($ carbohydrate $\times$ 4) $+($ fat $\times 9)]$

\section{Amino acid content of DMP}

Based on the method described by Pellet and Young (1980), the amino acid composition of mushroom was determined, using amino acid analyzer (LC 3000 Eppendorf) at Dessert Research Center's, Central Lab. Cairo, Egypt.

\section{Fatty acid profile analysis}

Fat content was extracted from mushroom samples according to Folch et al. (1957). Two drops of the remaining oil were dissolved in $5 \mathrm{ml}$ benzene (GC grade), $7 \mathrm{~mL}$ GC solvent $\left(1 \% \mathrm{H}_{2} \mathrm{SO}_{4}\right.$ in methanol) were added for the preparation of fatty acid methyl esters, and then the mixture was heated in the oven at $90^{\circ} \mathrm{C}$ for 90 min. Two $\mathrm{mL}$ of distilled water and shaked well until the mixture was separated into two layers. The upper layer was transferred into sodium sulfate to eliminate excess moisture. The filtrate was passed through a $0.22 \mu 1$ microfilter to be ready for injection in the GC column. A split injector and FID detector from ACME model 6100 GC (Young LIN Instrument Co., Korea) were used to complete the gas chromatographic investigation. Nitrogen was used as a carrier gas of 0.5 $\mathrm{ml} / \mathrm{min}$. The components were separated on $30 \mathrm{~m} \mathrm{SP}-$ 2380 fused-silica capillary column with $0.25 \mathrm{~mm}$ ID and $0.2 \mu \mathrm{m}$ film thickness (Supelco, Bellefonte, PA). The detector temperature was set at $260^{\circ} \mathrm{C}$, the injector temperature was set at $220^{\circ} \mathrm{C}$ and in split mode $(1: 80$ split ratio). The column was initially maintained for $5 \mathrm{~min}$ at $140^{\circ} \mathrm{C}$ and then raised to $240^{\circ} \mathrm{C}$ at rate of $4^{\circ} \mathrm{C} /$ min (modified method of Schumann and Siekmann, 2000).

\section{Mineral content of DMP}

Mineral content and trace elements were conducted according to ASTM (2002) using inductively coupled Argon plasma, iCAP 6500 Duo, Thermo Scientific, England. One thousand $\mathrm{mg} / \mathrm{L}$ multi-element certified standard solution, Merck, Germany was used as stock solution for instrument standardization.

\section{Determination of riboflavin and niacin using HPLC}

Vitamin B complex was extracted according to the method described in AOAC International (1990).

A reverse phase HPLC technique using HPLC ultimate 3000, UK, determined the vitamins. The following conditions were used to separate riboflavin and niacin: according to Ismail and Fun (2003):

Methanol-water-acetic acid glacial (65:35:0.1) was used as a mobile phase, in a flow rate of $1 \mathrm{~mL} / \mathrm{min}$, using UV detector $(280 \mathrm{~nm})$.

Comparison of retention time and spiking test with the riboflavin and niacin standard (Sigma, Co. Chemical, St. Louis, USA) was used to identify the riboflavin and niacin peak. The final concentration of the standard was represented in $100 \mu \mathrm{g} / \mathrm{mL}$.

\section{Statistical analysis}

All data recorded throughout the study were exposed to the analysis of variance techniques based on thedesign used by the Windows CoStat software package. Treatment means were separated and compared at a meaning level of 0.05 by the L.S.D test (Snedecor and Cochron, 1980). The winter error for the character of the two study dates (September through December and January through April) was homogeneous, as determined by the error homogeneity test (Hartley, 1950), so the data were combined over the two dates.

\section{RESULTS AND DISCUSSIONS}

\section{Yield and biological efficiency (BE) of Pleurotus ostreatus}

Oyster mushroom experiments growing on seven different agricultural waste substrates including wheat straw (WS), rice straw (RS), saw dust (SD) and water hyacinth (WH), either single or mixed with wheat straw (WS) 1:1 (WS: agro-waste) (w/w) were studied. In Table (1), the first initiation period on substrates $\mathrm{SD}+\mathrm{WS}, \mathrm{RS}$ and RS+WS were significantly shorter (28, 29 and 29 days, respectively), than the other substrates. On the other hand, the longest period of mycelium appearance was (38 days) recorded with substrate (WH). These findings are consistent with Hassan (2005) as the oyster mushroom cultivated on rice straw and a combination of rice straw with wheat straw provided a 
shorter period of mycelium appearance ( 28 and 29 days, respectively).

The earliness harvest of oyster mushroom ranged between 33-45 days, depending on the substrate used. The results showed that the first harvest of oyster mushroom grown on a mixture of (SD+WS), RS and a mixture of (RS+WS) was lower than the other samples (33, 34 and 34 days respectively, Table 1). Along these lines, this is a favorable position to deliver mushroom in brief time and could be a time economy.

The yield is one of the mushroom growers' main targets. All the oyster mushrooms grown on various substrates showed significant differences in mushroom yield performance (Tables 1 and 2). Therefore, the use of a diversity of the substrates is essential. In this study, the amount of mushroom yield using a mixture of (RS+WS) appeared a significantly highest mushroom yield $(7600 \mathrm{~g})$ throughout the three harvesting periods. The highest yield was followed by, oyster yields using (RS) alone during the three harvesting periods $(6650 \mathrm{~g})$. On the other hand, the lowest yield (3055 g) was recorded with cultivated mushroom using (WH) throughout the three harvesting periods. Commonly, in this study it was observed the trend gradually decreased from the first till the third harvesting periods for all produced mushroom (Table 2).

In term of biological efficiency (BE), mushroom produced from rice straw + wheat straw substrates (RS+WS) followed by (RS) had higher values than the other substrates (126.7 and $110.8 \%$, respectively). In general, substrates gave the higher yield also gave the higher value of BE. Whereas, substrate $100 \%$ (WH) followed by (SD) showed the lowest mushroom yield, as well as the lowest BE (Table 2). On the other hand, it was observed that the combination of the previous substrates (water hyacinth and saw dust) with WS at (1: 1) ratio $(\mathrm{WH}+\mathrm{WS}$ and $\mathrm{SD}+\mathrm{WS})$ improved the $\mathrm{BE}$ (50.9\% to $83.2 \%$ and $66.7 \%$ to $92.5 \%$, respectively). The results are compatible with Fawzi (2016) as the total yield was in highest levels in oyster mushroom cultivated on rice straw substrate followed by mixture of rice plus wheat straw $(3500$ and $3360 \mathrm{~g} / 4 \mathrm{~kg}$ substrate, respectively) also, their biological efficiency were 87 and $84 \%$, respectively).

Differences in yield and BE of oyster mushroom grown on different types of substrates were due to differences in the physical and chemical composition of substrate formulas such as cellulose/lignin ratio and mineral content, $\mathrm{pH}, \mathrm{EC}$ of substrate, in particular $\mathrm{C} / \mathrm{N}$ ratio. One of the factors influencing overall yield and BE compared to other substrates was low substrate nitrogen (Hoa et al., 2015). An easier way to obtain sugar from cellulosic substances is causing the increase in mushroom yield in rice straw (Ponmurugan et al., 2007). Pleurotus specie therefore requires carbon, nitrogen and inorganic compounds as their nutritional sources. The main nutrients are less nitrogen and more carbon, so materials containing cellulose, hemicellulose, and lignin (i.e. rice and wheat straw, cotton, sawdust, waste paper, leaves, and residue of sugarcane) can be used as mushroom substrates (Chang and Miles, 1989). Oyster mushroom may grow on a wide variety of substrates. The yield and quality of oyster mushrooms, however, depend on the chemical and nutritional content of substrates (Badu et al., 2011 and Patil et al., 2010).

Table 1. Effect of substrate on oyster mushroom production

\begin{tabular}{cccccccc}
\hline Substrates & WS & RS & RS+WS & SD & SD+WS & WH & WH+WS \\
\hline $\begin{array}{c}\text { First initiation } \\
\text { (day) }\end{array}$ & $34^{\mathrm{b}}$ & $29^{\mathrm{c}}$ & $29^{\mathrm{c}}$ & $33^{\mathrm{b}}$ & $28^{\mathrm{c}}$ & $38^{\mathrm{a}}$ & $33^{\mathrm{b}}$ \\
$\begin{array}{c}\text { Earliness } \\
\text { harvest (day) } \\
\begin{array}{c}\text { Total fresh } \\
\text { weight (g) }\end{array}\end{array}$ & $39^{\mathrm{bc}}$ & $34^{\mathrm{d}}$ & $34^{\mathrm{d}}$ & $38 \mathrm{c}$ & $33^{\mathrm{d}}$ & $45^{\mathrm{a}}$ & $40^{\mathrm{b}}$ \\
\hline
\end{tabular}

$\overline{\text { Values followed by the same values alphabetical letter(s) in common, within a particular group of means in each character, do not }}$ significantly differ, using Revised L.S.D test at 0.05 level of probability

$a, b, c, .$. Mean values in the same row between different treatments marked with unlike letters are significantly different $(\mathrm{p}<0.05)$

First initiation: The time elapsed between the day of inoculation and the day of the first apparent, Earliness harvest: The time elapsed between the day of inoculation and the day of the first harvest

Mixes are with ratio 1:1 (w/w). WS: mushroom cultivated on wheat straw, RS: mushroom cultivated on rice straw, RC+WS: mushroom cultivated on a mixture of rice straw and wheat straw, SD: mushroom cultivated on saw dust, SD+WS: mushroom cultivated on a mixture of saw dust and wheat straw, WH: mushroom cultivated on water hyacinth, WH +WS: mushroom cultivated on a mixture of water hyacinth and wheat straw. 
Table 2. Production yield of oyster mushroom during 3 harvesting periods

\begin{tabular}{cccccccc}
\hline Substrates & WS & RS & RS+WS & SD & SD+WS & WH & WH+WS \\
\hline $\begin{array}{c}\text { production weight }(\mathrm{g}) \\
1^{\text {st }} \text { harvest period }\end{array}$ & $2399^{\mathrm{d}}$ & $3210^{\mathrm{b}}$ & $3320^{\mathrm{a}}$ & $1650^{\mathrm{f}}$ & $2720^{\mathrm{c}}$ & $1415^{\mathrm{g}}$ & $2360^{\mathrm{e}}$ \\
$\begin{array}{c}\text { production weight }(\mathrm{g}) \\
\quad 2^{\text {nd }} \text { harvest period } \\
\text { production weight }(\mathrm{g})\end{array}$ & $1850^{\mathrm{c}}$ & $2100^{\mathrm{b}}$ & $2640^{\mathrm{a}}$ & $1250^{\mathrm{f}}$ & $1580^{\mathrm{d}}$ & $900^{\mathrm{g}}$ & $1560^{\mathrm{e}}$ \\
$\quad 3^{\text {rd }}$ harvest period & $1340^{\mathrm{c}}$ & $1640^{\mathrm{a}}$ & $1100^{\mathrm{e}}$ & $1250^{\mathrm{d}}$ & $740^{\mathrm{g}}$ & $1070^{\mathrm{f}}$ \\
$\begin{array}{c}\text { Biological efficiency } \\
\text { (BE) \% }\end{array}$ & $94.4^{\mathrm{c}}$ & $110.8^{\mathrm{b}}$ & $126.7^{\mathrm{a}}$ & $66.7^{\mathrm{f}}$ & $92.5^{\mathrm{d}}$ & $50.9^{\mathrm{g}}$ & $83.2^{\mathrm{e}}$
\end{tabular}

Values followed by the same alphabetical letter(s) in common, within a particular group of means in each character, do not significantly differ, using Revised L.S.D test at 0.05 level of probability.

$a, b, c, .$. Mean values in the same row between different treatments marked with unlike letters are significantly different $(p<0.05)$ WS: mushroom cultivated on wheat straw, RS: mushroom cultivated on rice straw, RC+WS: mushroom cultivated on a mixture of rice straw and wheat straw, SD: mushroom cultivated on saw dust, SD+WS: mushroom cultivated on a mixture of saw dust and wheat straw, WH: mushroom cultivated on water hyacinth, $\mathrm{WH}+\mathrm{WS}$ : mushroom cultivated on a mixture of water hyacinth and wheat straw

\section{Chemical Composition of DMP}

Table (3) presented fundamental nutritional characteristics; ash, fibre, protein, fat and carbohydrate content, in addition to energy value for $100 \mathrm{~g}$ of oyster mushroom grown on various substrates. The moisture content of fried oyster mushroom did not affect with different substrates which was (6.41-12.49\%). The highest moisture content of the oyster mushroom was due to the water holding capacity of the substrate. The result was very close to the stated value mentioned by Kurtzman (2005) and Ahmed et al. (2009), who reported that Pleurotus species grown on various agrowastes. Mushroom age, growing environments, mushroom strains, and post-harvest environments also influenced moisture content (Kurtzman, 2005).

The study indicated that the oyster mushroom grown on all substrates are quite rich in protein, carbohydrates and fibre content making them excellent foods that can be used in low caloric diets. Mushroom protein on a dry weight basis ranged from 19.21 to $29.76 \%$. This value is somewhat similar to the range reported by Kurtzman (2005) in which the dry matter-based protein in the oyster mushroom ranged from 20 to $40 \%$. The highest mushroom protein $(29.76 \%)$ was recorded with mushroom grown on (WH). While, mushroom grown on (RS) and (RS + WS) were recorded moderate protein values by (21.41 and 19.90\%), respectively. Differences in the protein content of mushrooms grown on different substrates may be due to substrates ' varying nitrogen content. Mushroom protein is an easily digested form and is also better than many legumes such as soybeans and peanuts and vegetable protein-producing foods (Chang and Buswell, 1996; Chang and Mshigeni, 2001).

In the cultivated oyster mushroom, the content of ether extract and fibre ranged from 3.12 to $5.64 \%$ and 10.095 to $13.38 \%$, respectively. The highest fibre content was obtained from the mushroom grown on (WH). Whereas, mushroom grown on (RS) and mixture of (RS + WS) showed the moderate fibre contents by (10.55 and $10.095 \%)$, respectively. The ether content of the extract obtained in the study is higher than that reported by Wang et al. (2000). While, the fibre content was comparable to that of Yehia (2012). For mushroom grown on (WH) and (RS), the carbohydrate content of oyster mushroom ranged from $36,688 \%$ to $50,968 \%$, respectively. Patil et al. (2010) reported that the $P$. ostreatus content of carbohydrates ranged from 50.50 to $55.33 \%$ grown on paddy straw, soybean straw and wheat straw. However, Sharma et al. 2013's findings, were $30.24 \sim 42.26 \%$ of $P$. ostreatus grown on various substrates. Substrate not only affected protein, carbohydrate and fat, but also influenced total oyster mushroom energy (Table 3). For oyster mushroom, the total energy contribution of the samples ranged from 296.23 to $327.69 \mathrm{kcal} / 100 \mathrm{~g}$ dry weights. Manzi et al. (2001) reported that $P$. ostreatus ' energy contribution was $300 \mathrm{kcal} / 100 \mathrm{~g}$, but obtained energy values in kcal / $100 \mathrm{~g}$ were somewhat higher than these findings.

\section{Amino acid profile of DMP}

Mushrooms are considered a good source of protein and amino acids as a consequence. The amino acid profile $(\mathrm{mg} / 100 \mathrm{~g})$ of $P$. ostreatus grown on various substrates has therefore been determined (Table 4). Mushrooms contain all the essential amino acids required by an adult (Pushpa and Purushothama, 2010). In the first picking of $P$. ostreatus, a number of 17 amino acids were estimated, with different levels. The highest values were observed for glutamic acid (8.68$21.02 \mathrm{mg} / 100 \mathrm{~g}$ ), aspartic acid (3.36-14.32 mg/100 g), alanine (5.60-12.05 mg/100 g), leucine (8.07-11.74 $\mathrm{mg} / 100 \mathrm{~g}$ ), lysine $(6.63-9.88 \mathrm{mg} / 100 \mathrm{~g})$, valine (5.51$9.55 \mathrm{mg} / 100 \mathrm{~g})$, proline $(6.54-8.87 \mathrm{mg} / 100 \mathrm{~g})$ and glycine $(5.25-8.50 \mathrm{mg} / 100 \mathrm{~g})$. While the lowest values 
Table 3. Chemical composition of dried oyster mushroom cultivated on different substrates Compositions \% Substrates

\begin{tabular}{cccccccc}
\hline & WS & RS & RS+WS & SD & SD+WS & WH & WH+WS \\
\hline Moisture content & $8.62^{\mathrm{e}}$ & $6.41^{\mathrm{g}}$ & $10.01^{\mathrm{b}}$ & $9.12^{\mathrm{c}}$ & $12.49^{\mathrm{a}}$ & $8.92^{\mathrm{d}}$ & $8.55^{\mathrm{f}}$ \\
Dry matter & $91.38^{\mathrm{c}}$ & $93.59^{\mathrm{a}}$ & $89.99^{\mathrm{f}}$ & $90.88^{\mathrm{e}}$ & $87.51^{\mathrm{g}}$ & $91.08^{\mathrm{d}}$ & $91.45^{\mathrm{b}}$ \\
Organic matter & $84.71^{\mathrm{b}}$ & $87.17^{\mathrm{a}}$ & $84.10^{\mathrm{e}}$ & $84.19^{\mathrm{d}}$ & $80.67^{\mathrm{g}}$ & $83.21^{\mathrm{f}}$ & $84.41^{\mathrm{c}}$ \\
Crude protein & $19.21^{\mathrm{g}}$ & $21.41^{\mathrm{d}}$ & $19.90^{\mathrm{f}}$ & $27.98^{\mathrm{b}}$ & $21.34^{\mathrm{e}}$ & $29.76^{\mathrm{a}}$ & $26.40^{\mathrm{c}}$ \\
Ether extract & $4.016^{\mathrm{a}}$ & $4.242^{\mathrm{a}}$ & $5.642^{\mathrm{a}}$ & $3.964^{\mathrm{a}}$ & $3.852^{\mathrm{a}}$ & $3.382^{\mathrm{a}}$ & $3.12^{\mathrm{a}}$ \\
Ash & $6.67^{\mathrm{e}}$ & $6.42^{\mathrm{f}}$ & $5.89^{\mathrm{g}}$ & $6.69^{\mathrm{d}}$ & $6.84^{\mathrm{c}}$ & $7.87^{\mathrm{a}}$ & $7.04^{\mathrm{b}}$ \\
NDF & $59.35^{\mathrm{a}}$ & $56.98^{\mathrm{c}}$ & $58.06^{\mathrm{b}}$ & $52.20^{\mathrm{e}}$ & $48.69^{\mathrm{g}}$ & $50.98^{\mathrm{f}}$ & $53.74^{\mathrm{d}}$ \\
ADF & $27.71^{\mathrm{c}}$ & $28.39^{\mathrm{b}}$ & $28.52^{\mathrm{a}}$ & $23.65^{\mathrm{f}}$ & $23.75^{\mathrm{e}}$ & $22.84^{\mathrm{g}}$ & $24.56^{\mathrm{d}}$ \\
Lignin & $0.29^{\mathrm{e}}$ & $0.42^{\mathrm{d}}$ & $4.85^{\mathrm{a}}$ & $0.55^{\mathrm{c}}$ & $0.25^{\mathrm{f}}$ & $0.55^{\mathrm{c}}$ & $0.75^{\mathrm{b}}$ \\
Hemicellulose & $31.64^{\mathrm{a}}$ & $28.59^{\mathrm{d}}$ & $29.54^{\mathrm{b}}$ & $28.55^{\mathrm{e}}$ & $24.94^{\mathrm{g}}$ & $28.14^{\mathrm{f}}$ & $29.18^{\mathrm{c}}$ \\
Cellulose & $27.42^{\mathrm{b}}$ & $27.97^{\mathrm{a}}$ & $23.67^{\mathrm{d}}$ & $23.10^{\mathrm{f}}$ & $23.50^{\mathrm{e}}$ & $22.29^{\mathrm{g}}$ & $23.81^{\mathrm{c}}$ \\
Crude fibre & $12.22^{\mathrm{ab}}$ & $10.55^{\mathrm{b}}$ & $10.095^{\mathrm{b}}$ & $10.8^{\mathrm{ab}}$ & $11.2^{\mathrm{ab}}$ & $13.38^{\mathrm{a}}$ & $12.484^{\mathrm{ab}}$ \\
Total available & & & & & & & \\
carbohydrates & $49.264^{\mathrm{b}}$ & $50.968^{\mathrm{a}}$ & $48.463^{\mathrm{c}}$ & $41.446^{\mathrm{f}}$ & $44.278^{\mathrm{d}}$ & $36.688^{\mathrm{g}}$ & $42.406^{\mathrm{e}}$ \\
Energy & $310.04^{\mathrm{d}}$ & $327.69^{\mathrm{a}}$ & $324.23^{\mathrm{b}}$ & $313.38^{\mathrm{c}}$ & $297.14^{\mathrm{f}}$ & $296.23^{\mathrm{g}}$ & $303.304^{\mathrm{e}}$ \\
\hline
\end{tabular}

Values followed by the same alphabetical letter(s) in common, within a particular group of means in each character, do not significantly differ, using Revised L.S.D test at 0.05 level of probability.

a,b,c,.. Mean values in the same row between different treatments marked with unlike letters are significantly different $(\mathrm{p}<0.05)$

NDF: Neutral detergent fiber, ADF: Acidic detergent fiber. The protein content $(\mathrm{N} \times 6.25)$ of samples was estimated

Total available carbohydrate $(\%)=[100-($ moisture + total ash + fibre + protein + fat $)]$.

Energy $(\mathrm{Kcal} / 100 \mathrm{gm})=[($ protein $\times 4)+($ Carbohydrate $\times 4)+($ fat $\times 9)]$. Values are represented in $\mathrm{g} / 100 \mathrm{~g}$ dry weight.

WS: mushroom cultivated on wheat straw, RS: mushroom cultivated on rice straw, RC+WS: mushroom cultivated on a mixture of rice straw and wheat straw, SD: mushroom cultivated on saw dust, SD+WS: mushroom cultivated on a mixture of saw dust and wheat straw, WH: mushroom cultivated on water hyacinth, WH +WS: mushroom cultivated on a mixture of water hyacinth and wheat straw

recorded by cysteine $(0.03-0.28 \mathrm{mg} / 100 \mathrm{~g})$ and methionine (1.1-1.61 $\mathrm{mg} / 100 \mathrm{~g})$. Water hyacinth combination with wheat straw $(\mathrm{WH}+\mathrm{WS})$ improved several $P$. ostreatus amino acids such as aspartic, threonine, serine, glutamic, proline, glycine, alanine, cysteine, valine, methionine, isoleucine, and leucine. Oyster mushroom grown on rice straw (RS) and a mixture of rice straw and wheat straw $(\mathrm{RC}+\mathrm{WS})$ was a moderate value of all determined amino acids compared to the other studied substrates. Pleurotus species are rich in glutamic acid, aspartic acid, lysine, leucine and threonine (Mdachi et al., 2004 and Kim et al., 2009). The differences in amino acids found in the same mushroom species may be a consequence of the genetic variation and cultivation process applied in commercial practices which was also revealed by Mendez et al., (2005).

\section{Fatty acid profile of DMP}

Fig (1) showed the results of the studied mushroom composition of fatty acids, total saturated fatty acids $\left(\mathrm{SFA}_{\mathrm{s}}\right)$, monounsaturated fatty acids $\left(\mathrm{MUFA}_{\mathrm{s}}\right)$, and polyunsaturated fatty acids $\left(\mathrm{PUFA}_{\mathrm{s}}\right)$. $\mathrm{PUFA}_{\mathrm{s}}$ were the main group of fatty acids compatible with other studies in all mushroom samples (D'iez and Alvarez, 2001).
The major fatty acid found was linoleic acid (C18:2), which contributed to PUFA's prevalence. The most abundant MUFA $_{\mathrm{s}}$ in all the samples was oleic acid (C18:1), while the major $\mathrm{SFA}_{\mathrm{s}}$ was palmitic acid (C16:0). In all the seven mushrooms tested, at least 71.41 and $27.6 \%$ of the total fatty acids were found to be unsaturated and saturated, respectively. The results of this study are consistent with linoleic (C18:2) and oleic (C18:1) acids in P. ostreatus lipids, reported by Pedneault et al. (2007) and Barros et al. (2008). They are also common precursors and intermediates in the biosynthesis and metabolism of other fatty acids. It should be noted that unsaturated fatty acids are basic and critical for our eating regimen and our health. All the mushrooms analysed contained high content of basic unsaturated fatty acids, cis-linoleic acid, as a source of basic unsaturated fatty acid (i.e. fatty acids that cannot be synthesized by higher animals, especially linoleic acid and fat-soluble vitamins (A, D, E, K). Essential fatty acids are fatty acids must be ingested by humans and other animals because the body requires them for good health but cannot synthesize them (Goodhart and Shils, 1980) with high amounts of cis-linoleic acid (18:2) in Pleurotus ostreatus (65.29\%). These results are consistent with previous reports that many species of 


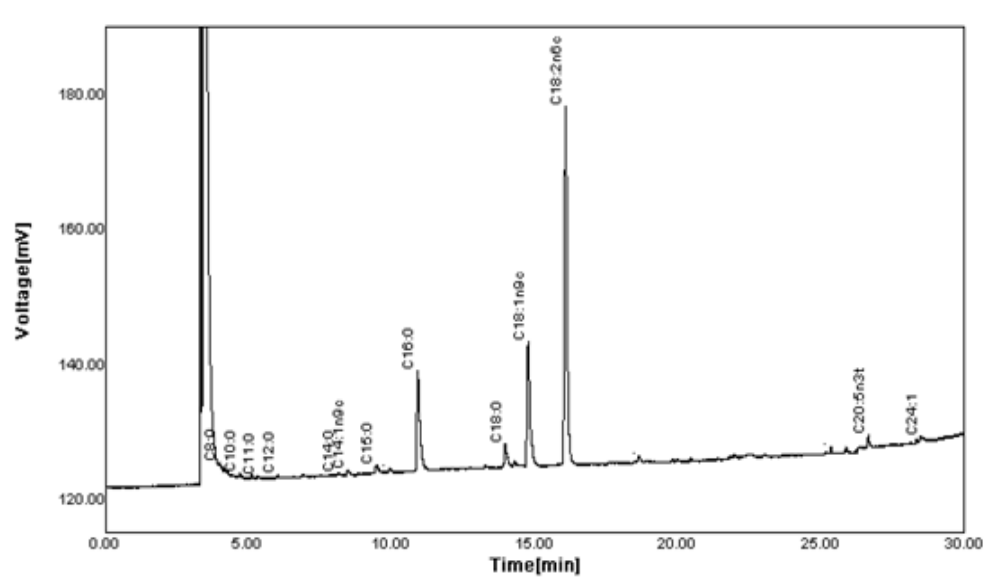

(a) Wheat straw

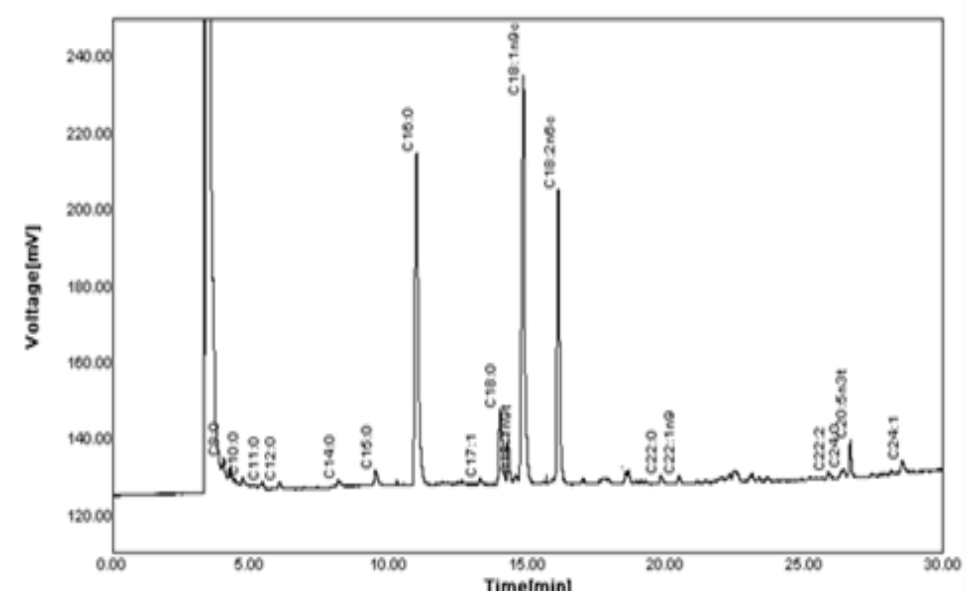

(c) Rice straw+wheat straw

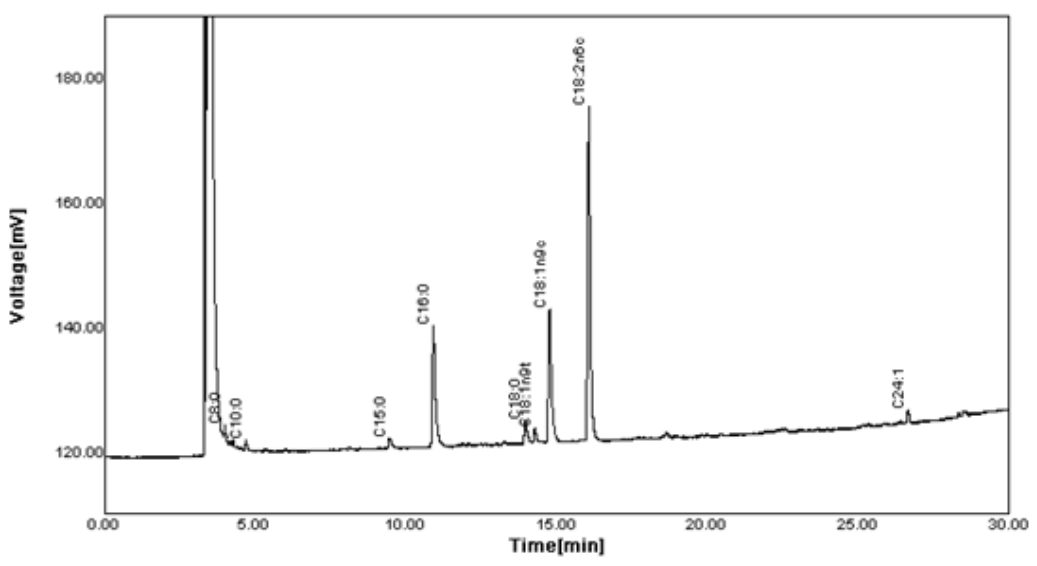

(b) Rice straw

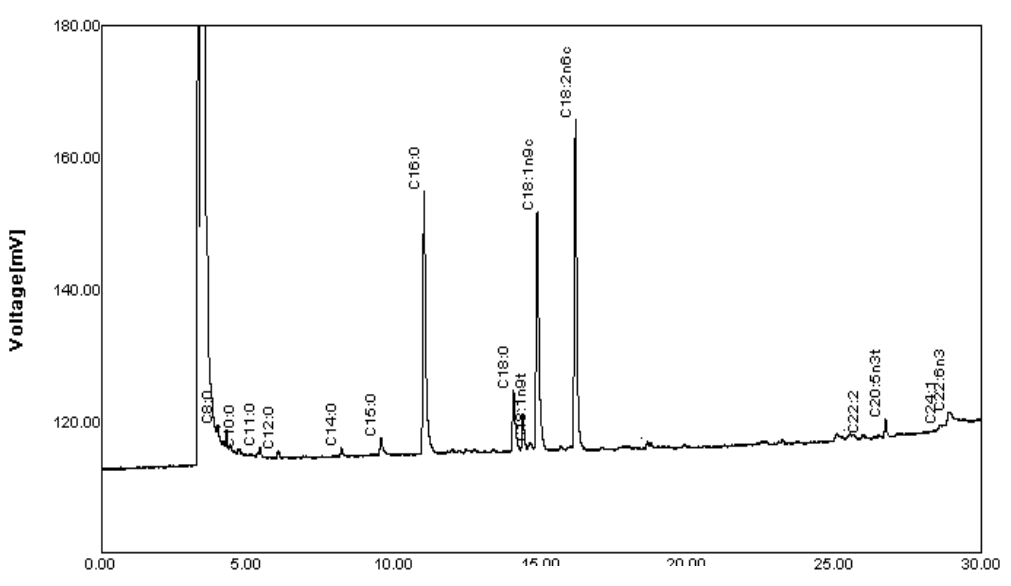

(d) Saw dust 


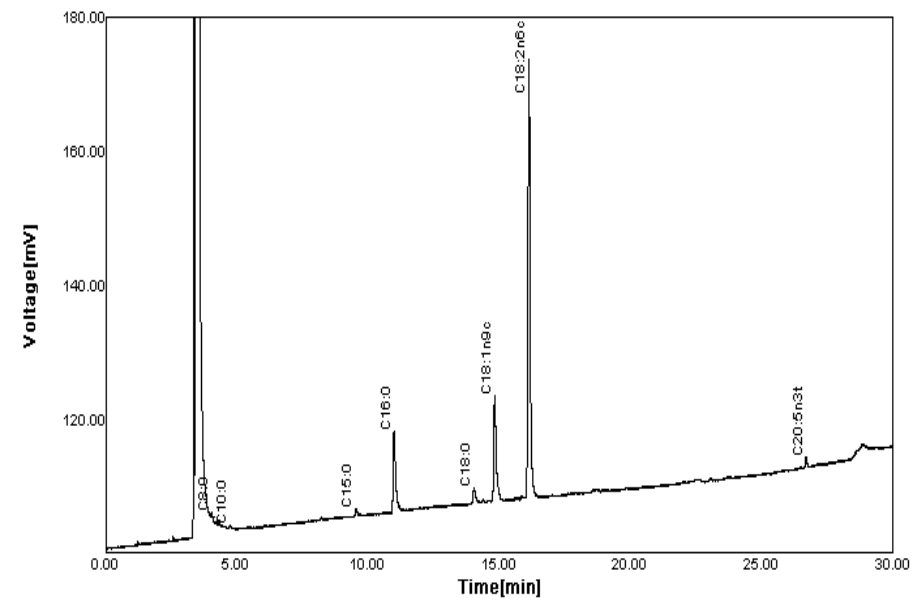

(e) Saw dust +wheat straw

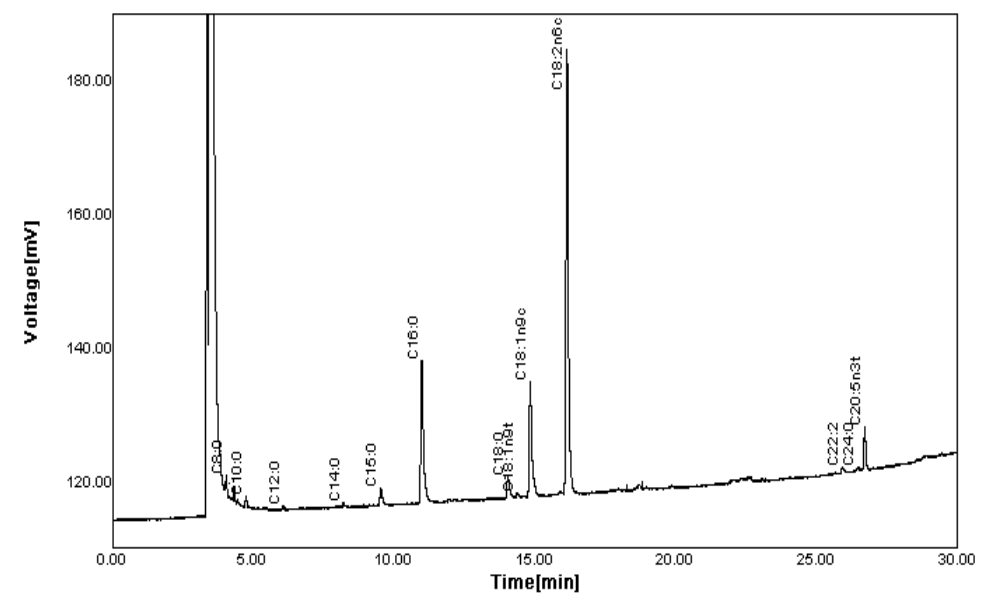

(f) Water hyacinth

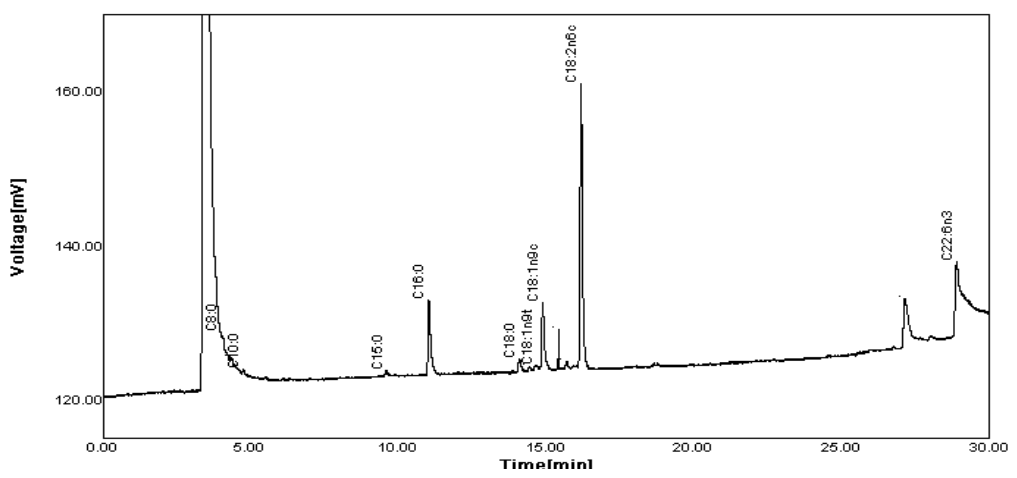

(g) Water hyacinth +wheat straw

Figure 1. Fatty acid profile (\%) of Pleurotus ostreatus cultivated on different substrates (a - g) 
mushrooms had high proportions of unsaturated fatty acids, particularly linoleic acid (Kalač, 2009 and Ruess et al., 2002). It is known that linoleic acid is the precursor of 1-octen-3-ol, known as fungal alcohol, which is the main aromatic compound in most fungi and may contribute to the flavour of mushrooms (Maga, 1981).

Fortunately, the mushrooms studied detected very low amounts of unsaturated fatty acid trans isomers (0.02-0.12\%) (Pelin et al., 2013). A rapidly expanding literature documents the importance of trans fatty acids (TFAs) in human health due to the increased risk of cardiovascular disease where they are negatively correlated with plasma concentrations of HDLcholesterol and positively correlated with plasma levels of LDL-cholesterol (Minamide and Hammond, 1985). It is also important to note that, unlike other fungi (D'rez and Alvarez, 2001 and Longvah and Deosthale, 1998), no other fatty acids with an odd number of carbon atoms were found in significant amounts.

\section{Minerals content of DMP}

Dietary minerals are essential for metabolic reactions, healthy bone formation, nerve impulse transmission, water regulation, and salt balance (Kalač and Svoboda, 2000). Mushrooms are a good source of minerals needed for human nutrition, so some minerals like iron, zinc, magnesium, potassium and phosphorus have been identified (Table 5). In general, the most abundant minerals in oyster mushroom cultivated on various substrates were magnesium, phosphorus and potassium. Magnesium (1515.6 mg/kg dry weight),

Table 4. Amino acid profile of dried oyster mushroom cultivated on different substrates

\begin{tabular}{|c|c|c|c|c|c|c|c|c|}
\hline $\begin{array}{l}\text { Essential A.A } \\
\text { Valine }\end{array}$ & WS & RS & RS+WS & SD & SD+WS & WH & WH+WS & $\begin{array}{l}\text { Estimated } \\
\text { A.A } \\
\text { requirements }\end{array}$ \\
\hline & & & & & & & & $\begin{array}{ll}\mathrm{mg} / \mathrm{kg} & \text { per } \\
\text { day } & \text { for } \\
\text { adultss }^{1} & \end{array}$ \\
\hline
\end{tabular}

Essential A.A

\begin{tabular}{|c|c|c|c|c|c|c|c|c|}
\hline Valine & $6.49^{\mathrm{f}}$ & $7.66^{d}$ & $7.03^{\mathrm{e}}$ & $8.58^{b}$ & $7.91^{c}$ & $5.51^{\mathrm{g}}$ & $9.55^{\mathrm{a}}$ & 10 \\
\hline Methionine & $1.10^{\mathrm{b}}$ & $1.39^{a b}$ & $1.22^{b}$ & $1.61^{\mathrm{a}}$ & $1.34^{\mathrm{ab}}$ & $1.23^{b}$ & $1.60^{\mathrm{a}}$ & \\
\hline Isoleucine & $5.08^{\mathrm{g}}$ & $5.98^{\mathrm{e}}$ & $5.51^{\mathrm{f}}$ & $6.66^{b}$ & $6.00^{d}$ & $6.53^{c}$ & $7.50^{\mathrm{a}}$ & 10 \\
\hline leucine & $8.07^{\mathrm{f}}$ & $9.42^{\mathrm{d}}$ & $8.62^{\mathrm{e}}$ & $10.60^{c}$ & $9.42^{\mathrm{d}}$ & $\begin{array}{c}10.80 \\
\mathrm{~b}\end{array}$ & $11.74^{\mathrm{a}}$ & 14 \\
\hline Phenyl alanine & $4.69^{\mathrm{g}}$ & $5.97^{\mathrm{e}}$ & $5.17^{\mathrm{f}}$ & $6.46^{c}$ & $6.09^{\mathrm{d}}$ & $7.51^{\mathrm{a}}$ & $7.03^{b}$ & \\
\hline Histidine & $2.99^{\mathrm{g}}$ & $3.59^{\mathrm{e}}$ & $3.31^{\mathrm{f}}$ & $3.99^{\mathrm{c}}$ & $3.64^{\mathrm{d}}$ & $4.72^{\mathrm{a}}$ & $4.69^{b}$ & $8-12$ \\
\hline Lysine & $6.71^{\mathrm{f}}$ & $7.83^{d}$ & $6.89^{e}$ & $8.99^{c}$ & $6.63^{g}$ & $9.88^{\mathrm{a}}$ & $9.81^{\mathrm{b}}$ & 12 \\
\hline Threonine & $3.65^{\mathrm{ab}}$ & $4.33^{\mathrm{ab}}$ & $3.91 \mathrm{ab}$ & $4.80^{\mathrm{a}}$ & $4.39^{\mathrm{a}}$ & $1.58^{b}$ & $5.22^{\mathrm{a}}$ & 7 \\
\hline $\begin{array}{l}\text { Non essential } \\
\text { A.A }\end{array}$ & & & & & & & & \\
\hline Proline & $6.54^{\mathrm{g}}$ & $7.45^{\mathrm{d}}$ & $6.73^{f}$ & $8.15^{b}$ & $7.42^{\mathrm{e}}$ & $7.77^{\mathrm{c}}$ & $8.87^{\mathrm{a}}$ & \\
\hline Glutamic acid & $14.37^{\mathrm{f}}$ & $17.90^{\mathrm{d}}$ & $15.92^{\mathrm{e}}$ & $20.95^{b}$ & $20.93^{c}$ & $8.68^{\mathrm{g}}$ & $21.02^{\mathrm{a}}$ & \\
\hline Glycine & $6.12^{\mathrm{ab}}$ & $6.92^{a b}$ & $5.95^{\mathrm{ab}}$ & $7.94^{\mathrm{ab}}$ & $6.92^{\mathrm{ab}}$ & $5.25^{b}$ & $8.50^{\mathrm{a}}$ & \\
\hline Alanine & $7.85^{f}$ & $9.65^{\mathrm{d}}$ & $8.59^{\mathrm{e}}$ & $10.88^{c}$ & $12.05^{\mathrm{a}}$ & $5.60^{\mathrm{g}}$ & $11.75^{b}$ & \\
\hline Cystine & $0.28^{\mathrm{a}}$ & $0.10^{\mathrm{e}}$ & $0.06^{\mathrm{f}}$ & $0.03^{\mathrm{g}}$ & $0.18^{\mathrm{b}}$ & $0.11^{\mathrm{d}}$ & $0.16^{\mathrm{c}}$ & \\
\hline Tyrosine & $1.99^{\mathrm{g}}$ & $2.41^{\mathrm{e}}$ & $2.25^{\mathrm{f}}$ & $2.81^{\mathrm{c}}$ & $2.62^{\mathrm{d}}$ & $3.10^{\mathrm{a}}$ & $2.91^{\mathrm{b}}$ & \\
\hline Serine & $2.46^{\mathrm{ab}}$ & $2.76^{\mathrm{a}}$ & $2.51^{\mathrm{ab}}$ & $3.20^{\mathrm{a}}$ & $2.39^{\mathrm{ab}}$ & $0.97^{\mathrm{b}}$ & $3.26^{\mathrm{a}}$ & \\
\hline Aspartic acid & $10.56^{\mathrm{bc}}$ & $11.61^{\mathrm{abc}}$ & $11.10^{\mathrm{bc}}$ & $\underset{\mathrm{ab}}{12.57}$ & $9.41^{\mathrm{c}}$ & $3.36^{\mathrm{d}}$ & $14.32^{\mathrm{a}}$ & \\
\hline Arginine & $2.60^{a b}$ & $2.90^{a b}$ & $2.75^{a b}$ & $3.62^{\mathrm{ab}}$ & $2.34^{b}$ & $4.52^{\mathrm{a}}$ & $3.91^{\mathrm{ab}}$ & \\
\hline
\end{tabular}

Values followed by the same alphabetical letter(s) in common, within a particular group of means in each character, do not significantly differ, using Revised L.S.D test at 0.05 level of probability

$a, b, c, .$. Mean values in the same row between different treatments marked with unlike letters are significantly different $(p<0.05)$. Amino acid content is represented in $\mathrm{mg} / \mathrm{g}$ dry weight

WS: mushroom cultivated on wheat straw, RS: mushroom cultivated on rice straw, RC+WS: mushroom cultivated on a mixture of rice straw and wheat straw, SD: mushroom cultivated on saw dust, SD+WS: mushroom cultivated on a mixture of saw dust and wheat straw, WH: mushroom cultivated on water hyacinth, WH +WS: mushroom cultivated on a mixture of water hyacinth and wheat straw.

${ }^{1}$ Based on highest estimate of requirement to achieve nitrogen balance. Data from several investigators (reviewed in FAO/WHO, 1973). 
Table 5. Mineral contents of dried oyster mushroom cultivated on different substrates

\begin{tabular}{cccccccccccccccc}
\hline Substrates & $\mathbf{C a}$ & $\mathbf{C o}$ & $\mathbf{C r}$ & $\mathbf{C u}$ & $\mathbf{F e}$ & $\mathbf{M g}$ & $\mathbf{M n}$ & $\mathbf{M o}$ & $\mathbf{N i}$ & $\mathbf{V}$ & $\mathbf{Z n}$ & $\mathbf{P}$ & $\mathbf{K}$ & $\mathbf{N a}$ \\
\hline WS & $102.8^{\mathrm{f}}$ & $0.001^{\mathrm{a}}$ & $6.86^{\mathrm{b}}$ & $13.46^{\mathrm{c}}$ & $79.35^{\mathrm{c}}$ & $1140.2^{\mathrm{g}}$ & $4.33^{\mathrm{b}}$ & $0.001^{\mathrm{a}}$ & $0.352^{\mathrm{bcd}}$ & $0.01^{\mathrm{b}}$ & 44.47 & $6548.4^{\mathrm{e}}$ & $140^{\mathrm{d}}$ & $7^{\mathrm{a}}$ \\
RS & $124.7^{\mathrm{e}}$ & $0.001^{\mathrm{a}}$ & $1.22^{\mathrm{d}}$ & $13.27^{\mathrm{d}}$ & $106.02^{\mathrm{b}}$ & $1202.1^{\mathrm{e}}$ & $6.44^{\mathrm{ab}}$ & $0.001^{\mathrm{a}}$ & $1.899^{\mathrm{a}}$ & $0.01^{\mathrm{b}}$ & $46.83^{\mathrm{e}}$ & $5975.4^{\mathrm{f}}$ & $160^{\mathrm{c}}$ & $5^{\mathrm{b}}$ \\
RS+WS & $93.8^{\mathrm{g}}$ & $0.001^{\mathrm{a}}$ & $2.27^{\mathrm{cd}}$ & $13.14^{\mathrm{f}}$ & $66.09^{\mathrm{d}}$ & $1189.5^{\mathrm{f}}$ & $5.91^{\mathrm{ab}}$ & $0.001^{\mathrm{a}}$ & $0.210^{\mathrm{cd}}$ & $0.01^{\mathrm{b}}$ & $38.84^{\mathrm{g}}$ & $5887.4^{\mathrm{g}}$ & $150^{\mathrm{cd}}$ & $4^{\mathrm{c}}$ \\
SD & $280.5^{\mathrm{a}}$ & $0.001^{\mathrm{a}}$ & $2.52^{\mathrm{cd}}$ & $13.05^{\mathrm{g}}$ & $70.61^{\mathrm{d}}$ & $1506.3^{\mathrm{b}}$ & $6.27^{\mathrm{ab}}$ & $0.001^{\mathrm{a}}$ & $0.418^{\mathrm{bc}}$ & $0.234^{\mathrm{a}}$ & $54.39^{\mathrm{b}}$ & $10248.4^{\mathrm{b}}$ & $180^{\mathrm{b}}$ & $3^{\mathrm{d}}$ \\
SD+WS & $155.4^{\mathrm{b}}$ & $0.001^{\mathrm{a}}$ & $2.94^{\mathrm{c}}$ & $13.20^{\mathrm{e}}$ & $250.74^{\mathrm{a}}$ & $1515.8^{\mathrm{a}}$ & $6.71^{\mathrm{ab}}$ & $0.001^{\mathrm{a}}$ & $0.429^{\mathrm{b}}$ & $0.01^{\mathrm{b}}$ & $53.26^{\mathrm{c}}$ & $7836.5^{\mathrm{d}}$ & $150^{\mathrm{cd}}$ & $4^{\mathrm{c}}$ \\
WH & $142.3^{\mathrm{c}}$ & $0.001^{\mathrm{a}}$ & $10.96^{\mathrm{a}}$ & $16.95^{\mathrm{a}}$ & $70.32^{\mathrm{d}}$ & $1436.2^{\mathrm{c}}$ & $7.90^{\mathrm{a}}$ & $0.001^{\mathrm{a}}$ & $0.189^{\mathrm{d}}$ & $0.01^{\mathrm{b}}$ & $61.58^{\mathrm{a}}$ & $10924.4^{\mathrm{a}}$ & $200^{\mathrm{a}}$ & $4^{\mathrm{c}}$ \\
WH+WS & $138.9^{\mathrm{d}}$ & $0.001^{\mathrm{a}}$ & $3.54^{\mathrm{c}}$ & $16.49^{\mathrm{b}}$ & $69.82^{\mathrm{d}}$ & $1295.0^{\mathrm{d}}$ & $6.33^{\mathrm{ab}}$ & $0.001^{\mathrm{a}}$ & $0.338^{\mathrm{bcd}}$ & $0.01^{\mathrm{b}}$ & $50.21^{\mathrm{d}}$ & $9115.8^{\mathrm{c}}$ & $180^{\mathrm{b}}$ & $4^{\mathrm{c}}$ \\
\hline
\end{tabular}

Values followed by the same alphabetical letter(s) in common, within a particular group of means in each character, do not significantly differ, using Revised L.S.D test at 0.05 level of probability

$\mathrm{a}, \mathrm{b}, \mathrm{c}, .$. Mean values in the same row between different treatments marked with unlike letters are significantly different ( $<<0.05$ ). Minerals content is represented in $\mathrm{mg} / \mathrm{kg}$ dry weight.

WS: mushroom cultivated on wheat straw, RS: mushroom cultivated on rice straw, RC+WS: mushroom cultivated on a mixture of rice straw and wheat straw, SD: mushroom cultivated on saw dust, SD+WS: mushroom cultivated on a mixture of saw dust and wheat straw, WH: mushroom cultivated on water hyacinth, WH + WS: mushroom cultivated on a mixture of water hyacinth and wheat straw. 
recorded the highest values in oyster mushroom grown on combination of (SD+WS) from the first picking. Whereas, oyster mushroom grown on RS and the mixture of (RS+WS) represented moderate values of this mineral (1202.1 and $1189.5 \mathrm{mg} / \mathrm{kg}$ dry weight, respectively). Potassium and phosphorus were the highest values in oyster mushroom grown on water hyacinth $(200 \mathrm{mg} / \mathrm{kg}$ dry weight and $10924.4 \mathrm{mg} / \mathrm{kg}$ dry weight, respectively). Peter (1991) agreed with the results obtained in which oyster mushrooms generally contained substantial amounts of phosphorus, magnesium and potassium and lower levels of sodium, iron and zinc. The oyster mushroom grown on RS and the mixture of (RS+WS) represented moderate values of copper, manganese, potassium and sodium (13.27$13.14,6.44-5.91,160-150$ and $5-4 \mathrm{mg} / \mathrm{kg}$ dry weight, respectively). There is a good balance between high $\mathrm{K}$ content and low Na content, and thus may be involved in curing high blood pressure (Manzi et al., 1999). According to the recommended dietary allowance (National Research Council, 1989), 100g of mushroom could supply all the necessary amounts of phosphorus, iron, magnesium, $8-15 \%$ sodium and half potassium and zinc requirements for human diet. In general, in comparison with vegetables, mushroom species provide a reasonable amount of minerals (Guillamón et al., 2010).

\section{Riboflavin and niacin DMP}

Mushrooms are an important vitamin source. Group $\mathrm{B}$ vitamins are abundant, including thiamine (B1), riboflavine (B2), pantothenic acid (B5), folic acid (B9), and other vitamins such as ergosterol, biotin, and tocopherols (Breene, 1990; Mattila et al., 1994 and 2001). Dudka et al. (1992) reported that Pleurotus mushroom's fruiting bodies contained high amounts of vitamin B group such as vegetables. Therefore, in oyster mushroom samples grown on different substrates, niacin and riboflavin were determined (Table 6).

Table 6. Vitamin contents of dried oyster mushroom cultivated on different substrates

\begin{tabular}{ccc}
\hline Substrates & Riboflavin & Niacin \\
\hline WS & $2417.63^{\mathrm{a}}$ & $27958.3^{\mathrm{b}}$ \\
RS & $135.38^{\mathrm{d}}$ & $612.63^{\mathrm{c}}$ \\
RS+WS & $116.38^{\mathrm{d}}$ & $5129.69^{\mathrm{bc}}$ \\
SD & $119.38^{\mathrm{d}}$ & $1298.34^{\mathrm{c}}$ \\
SD+WS & $696.64^{\mathrm{c}}$ & $143378.5^{\mathrm{a}}$ \\
WH & $2481.41^{\mathrm{a}}$ & $1097.45^{\mathrm{c}}$ \\
WH+WS & $1596.55^{\mathrm{b}}$ & $3910.64^{\mathrm{bc}}$ \\
\hline
\end{tabular}

Values followed by the same alphabetical letter(s) in common, within a particular group of means in each character, do not significantly differ, using Revised L.S.D test at 0.05 level of probability

$a, b, c, .$. Mean values in the same row between different treatments marked with unlike letters are significantly different $(\mathrm{p}<0.05)$. Vitamin contents are represented in $\mu \mathrm{g} / 100$ g dry weight.

WS: mushroom cultivated on wheat straw, RS: mushroom cultivated on rice straw, RC+WS: mushroom cultivated on a mixture of rice straw and wheat straw, SD: mushroom cultivated on saw dust, SD+WS: mushroom cultivated on a mixture of saw dust and wheat straw, WH: mushroom cultivated on water hyacinth, WH +WS: mushroom cultivated on a mixture of water hyacinth and wheat straw.

The results indicated that high amounts of riboflavin were found in the first picking of oyster mushroom grown on (WH) and (WS) (2481.407 and $2417.63 \mu \mathrm{g} / 100 \mathrm{~g}$, respectively). While in oyster mushroom grown on combination of rice straw and wheat straw $(116.38 \mu \mathrm{g} / 100 \mathrm{~g})$, the lowest value was observed. Niacin's highest values were recorded in oyster mushroom grown on the mixture of (SD+WS), (WS), and the mixture of (RS+WS) $(143378.5,27958.3$, and $5129.69 \mu \mathrm{g} / 100 \mathrm{~g}$ ). Therefore, mushrooms grown on RS or WS or their mixtures (RS +WS) were considered a good source of these vitamins.

\section{CONCLUSION}

Different substrates have affected $P$. ostreatus ' nutrient composition in this experiment. The overall nutritional potential of the mushrooms was relatively different from other research findings, despite differences in the chemical composition of $P$. ostreatus grown on different substrates. Since many variables affect the composition of a given species, it is often impossible to compare the results obtained by different researchers working with the same species of mushrooms. However, the present results indicate that significant amounts of valuable fatty acids are contained in economically important wild edible mushrooms. It can also provide economic incentives for agribusiness to look at these residues as valuable resources and develop new businesses to use them to produce nutritious mushroom products. Mushroom cultivation can therefore become one of the most profitable agribusinesses that can produce food products from various substrates and help to dispose of them in an environmentally friendly way. Individual substrate supported mushroom growth, but in nutritional composition the mixed substrate is better than pure substrate. It can be inferred from the study that the combination of rice straw with wheat straw may serve as good substrate for growing better yield as well as quality oyster mushroom. The availability and economy of such substrates is one of the advantages of using them in this study.

The mushroom's application in dairy products will provide good source of food with high nutrition and prevent some disease, this is a prospect study which will be discussed in the following papers. 


\section{CONFLICT OF INTEREST}

The authors do not have any conflicts of interest.

\section{ACKNOWLEDGEMENT}

This study is a part of project entitled: Vigorous mushroom fermented milk summit proceeding. Funded by the Academy of Scientific Research and Technology, Egypt. Project ID 22.

\section{REFERENCES}

Ahmed, S.A., J.A. Kadam, V.P. Mane, S.S. Patil and M.M. Baig. 2009. Biological efficiency and nutritional contents of Pleurotus florida (Mont.) Singer cultivated on different agro-wastes. Nature and Science of sleep.7: 44-48.

American Society for Testing and Materials (ASTM). 2002. Water and environmental technology. In: Annual book of ASTM standards, vol. 11.01-11.02. West Conshohocken, USA.

AOAC. International. 1990. Official methods of analysis. association of official analytical chemists. $15^{\text {th }}$ ed. Arlington, Virginia. USA.

AOAC. International. 2006. Official methods of analysis. association of official analytical chemists. $18^{\text {th }} \mathrm{ed}$ Arlington, Virginia. USA

Badu, M., S.K. Twumasi and N.O. Boadi. 2011. Effect of lignocellulosic in wood used as substrate on the quality and yield of mushrooms. Food and Nutrition Sciences. 2: 780-784.

Barros, L., S. Falcao, P. Baptista, C. Freire, M. Vilas-Boas and I. Ferreira. 2008. Antioxidant activity of Agaricus sp. Mushrooms by chemical, biochemical and electrochemical assays. Food Chemistry. 111: 61-66.

Breene, W.M. 1990. Nutritional and medicinal value of specialty mushrooms. Journal of Food Protection. 53: 883894.

Chang, S.T. and P.G. Miles. 1989. Edible mushroom and their cultivation. CRC Press Inc., Boca Raton: Florida. USA.

Chang, S.T. and J.A. Buswell. 1996. Mushroom nutriceuticals. World Journal of Microbiology and Biotechnology. 12: 473-476.

Chang, S.T. and K.E. Mshigeni. 2001. Mushroom and their human health: their growing significance as potent dietary supplements. The University of Namibia, Windhoek. pp.179.

D’lez, V.A. and A. Alvarez. 2001. Compositional and nutritional studies on two wild edible mushrooms from northwest Spain. Food Chemistry. 75: 417-422.

Dudka, I.A., N.A. Bis'ko and V.T. Bilă. 1992. Cultivation of edible fungi. Urozhă, Kiev, Ukrania. p.160.

Elmastas, M., O. Isildak, I. Turkekul and N. Temur. 2007. Determination of antioxidant activity and antioxidant compounds in wild edible mushrooms. Journal of Food Composition and Analysis. 20:337-345.

Fawzi, Y. 2016. Oyster mushroom, effect of different substrates on the production, quality and antioxidant activity of oyster mushroom. LAP Lambert academic publishing, Deutschland, Germany. p. 107.
Folch, J., M. Lees and S.G.H. Sloane. 1957. A simple method for the isolation and purification of total lipides from animal tissues. Journal of Biological Chemistry. 226:497509.

Goodhart, R.S. and M.E. Shils. 1980. Modern nutrition in health and disease, $6^{\text {th }}$ ed.: Lea and febiger, Philadelphia; USA. p. 1370

Guillamón, E., A. García, M. Lozano, M. D’Arrigo, M.A. Rostagno, A. Villares and J.A. Martínez. 2010. Edible mushrooms: role in the prevention of cardiovascular diseases. Fitoterapia. 81: 715-723.

Hartley, H.O.1950. The Maximum F-ratio as a Short-cut Test for Heterogeneity of variance. Biometrika. 37: 308-312.

Hassan, SH. M. 2005. Studies on oyster mushroom (Pleurotus spp) MSc. Thesis, Faculty of Agriculture,Alexandria University, Egypt.

Hoa, H.T., C.L. Wang and C.H. Wang. 2015. The Effects of different substrates on the growth, yield, and nutritional composition of two oyster mushrooms (Pleurotus ostreatus and Pleurotus cystidiosus). Mycobiology. 43: 423-434.

Ismail, A. and C.S. Fun. 2003. Determination of Vitamin C, $\beta$ carotene and Riboflavin Contents in Five Green Vegetables Organically and Conventionally Grown. Malysian Journal of Nutrition. 9: 31-39.

Kalač, P. and L. Svoboda. 2000. A review of trace element concentrations in edible mushrooms. Food Chemistry. 69: 273-281.

Kalač, P. 2009. Chemical composition and nutritional value of European species of wild growing mushrooms: A review, Food Chemistry. 113: 9-16.

Kaushlesh, K.Y., G. Neelima, P.K. Shukla, S. Kumar and Y. Preeti. 2012. Preliminary studies on utilization of fruit waste composts for production of Oyster mushroom, Pleurotus florida (Mont.) Singer. Mushroom Research. 21: 75-78.

Khan, S.M., A.G. Kausar and M.A. Ali. 1981. Yield performance of different strains of oyster mushroom (Pleurotus spp.) on paddy straw in Pakistan. Mushroom Science. $11: 675-678$.

Kim, M.Y., M.I. Chung, S.J. Lee, J.K. Ahn, E.H. Kim, M.J. Kim, S.L. Kim, H. I. Moon, H.M. Ro, E.Y. Kang, S.H. Seo and H.K. Song. 2009. Comparison of free amino acid, carbohydrate concentrations in Korean edible and medicinal mushrooms. Food Chemistry. 113: 386 - 393.

Kurtzman, R.H. 2005. A review mushrooms: sources for modern western medicine. Micologia Aplicada International. 17: 21-33.

Longvah, T. and Y.G. Deosthale. 1998. Compositional and nutritional studies on edible wild mushroom from northeast India. Food Chemistry. 63: 331-334.

Maga, J.A. 1981. Mushroom flavor. Journal of Agricultural and Food Chemistry. 29: 1-4.

Manzi, P., L. Gambelli, S. Marconi, V. Vivanti and L. Pizzoferrato. 1999. Nutrients in edible mushrooms: an Inter-species Comparative Study. Food Chemistry. 65: 477 $-482$.

Manzi, P., A. Aguzzi and L. Pizzoferrato. 2001. Nutritional value of mushrooms widely consumed in Italy. Food Chemistry. 73: 321-325. 
Mattila, P.H., V.I. Piironen, R. Uusi and P.E. Koivistoinen. 1994. Vitamin D contents in edible mushroom. Journal of Agricultural and Food Chemistry. 42: 2449-2453.

Mattila, P.H., K. Konko, M. Eurola, J.M. Pihlawa, J. Astola, V. Lietaniemi, J. Kumpulainen, M. Valtonen and V. Piironen. 2001. Contents of vitamins, mineral elements, and some phenolic compounds in cultivated mushrooms. Journal of Agricultural and Food Chemistry. 49: 2343 2348 .

Mdachi, S.M., M.H. Nkunya, V.A. Nyigo and I.T. Urasa. 2004. Amino acid composition of some Tanzanian wild mushrooms. Food Chemistry. 86: 179-182.

Mendez, L.A., C.A. Castro, R.B. Casso and C.M. Leal. 2005. Effect of substrate and harvest on the amino acid profile of oyster mushroom (Pleurotus ostreatus). Journal of Food Composition and Analysis. 18: 447-450.

Minamide, T. and J.W. Hammond. 1985. The influence of the periodic fruiting (flushing) cycle on the biochemical development of Agaricus bisporus sporophores. New Phytologist. 100: 571-578.

National research council. 1989. Recommended Dietary Allowances, $10^{\text {ed }}$ Food and Nutrition Board, Commission on Life Sciences. National academy press, Washington. D.C.pp. 284 .

Oei and B.Van Nieuwenhuijzen. 2005. Growing oyster mushrooms on pasteurised or 'sterilised' substrates. In: Small-scale mushroom cultivation oyster, shiitake and wood ear mushrooms. Agromisa Foundation and CTA, Netherland. 37-56.

Pandey, R.S. and S.K. Ghosh. 1996. A Handbook on cultivation of mushroom. Emkay Publications Delhi. 134140.

Patil, S.S., S.A. Ahmed, S.M. Telang and M.M. Baig. 2010. The nutritional value of Pleurotus ostreatus (Jacq.:Fr) Kumm cultivated on different lignocellulosic agro-wastes. Innovative Romanian Food Biotechnolog. 7:66-76.

Pedneault, K.K., P. Angers, T. Avis, A. Gosselin and R.J. Tweddel. 2007. Fatty acid profiles of polar and Nonpolar lipids of Pleurotus ostreatus and P. cornucopiae var. 'citrino-pileatus' Grown at different temperatures. Mycological Research. 111: 1228-1234.

Pellet, P.L. and V.R. Young. 1980. Nutritional Evaluation of Protein Foods. Report of a working group sponsored by the International Union of Nutritional Sciences and the United Nations University World Hunger Programme. The United Nations University.

Pelin, G.E., A. Ilgaz, K. Fatih and E. Bülent. 2013. Fatty acid compositions of six wild edible mushroom species. The Scientific World Journal. 2013: 1-4.

Peter, O. 1991. Nutritional aspects and medical use. Manual on mushroom cultivation. Published by Tool Foundation, Amsterdam. 1: 23-24.
Piska, K., K. Sułkowska-Ziaja and B. Muszyńska. 2017. Edible mushroom Pleurotus ostreatus (Oyster mushroom) - its dietary significance and biological activity. Acta Scientiarum. Pollonorum. Hortorum Cultus. 16: 151-161.

Ponmurugan, P.Y., N. Sekhar and T.R. Sreesakthi. 2007. Effect of various substrates on the growth and quality of mushrooms. Pakistan journal of Biological Sciences. 10:171-173

Robertson, J.B. and S.P.J.Van. 1981. The detergent system of analysis and its application to human foods. In: The analysis of dietary fiber in food. (W. P. T. James and O. Theander, eds.), Marcel Dekker, New York. pp. 123-158.

Royse, D.J., S.L. Fales, and K. Karunanandaa. 2004. Influence of formaldehyde-treated soybean and commercial nutrient complementation on mushroom (Pleurotus sajor-caju) yield and in-vitro dry matter digestibility of spent substrate. Applied Microbiology and Biotechnology. 36:425- 429.

Ruess, L.M., M.M. Häggblom, Z.E.J. García and J. Dighton. 2002. Fatty acids of fungi and nematodes-possible biomarkers in the soil food chain? Soil Biology and Biochemistry. 34: 745-756.

Schumann, K. and K. Siekmann. 2000. Soaps. In: ULLMANN'S Encyclopedia of Industrial Chemistry Weinheim: Wiley- VCH. 241-261.

Sharma, S., R.K. Yadav and C.P. Pokhrel. 2013. Growth and yield of oyster mushroom (Pleurotus ostreatus) on different substrates. Journal of New Biological Reports. 2:3-8.

Snedecor, G.W. and W.G. Cochron. 1980. Statistical Method $7^{\text {th }}$ ed. Iowa State University Press. USA. pp.507.

The Ministry of Environment report- Egypt. 2014. (www.eeaa.gov.eg/ us/mediacenter/reports/soereports.aspx).

Van Soest, P.J., J.B. Robertson and B.A. Lewis. 1991. Methods for dietary fibre, neutral detergent fibre, and nonstarch polysaccharides in relation to animal nutrition. Journal of Dairy Science. 74: 3583-3597.

Wang, D., A. Sakoda and M. Suzuki. 2000. Biological efficiency and nutritional value of Pleurotus ostreatus cultivated on spent beer grain. Bioresouree Technology. 78: 293-300.

Yang, W.J., F.L. Guo and Z.J. Wan. 2013.Yield and size of oyster mushroom grown on rice/wheat straw basal substrate supplemented with cotton seed hull. Saudi Journal of Biological Sciences. 20: 333-338.

Yehia, R.S. 2012. Nutritional value and biomass yield of the edible mushroom Pleurotus ostreatus cultivated on different wastes in Egypt. Innovative Romanian Food Biotechnology. 11: 9-14. 


\section{الملخص العربي}

\section{تقييم زراعة المشروم (المحارى )على البيئات العضوية المختلفة}

عيشة محمد العطار ، شيماء محمد رجب حسن، شيرين فاضل علي عوض الله

قد أعطت أعلى كمية محصول من ثمار فطر عيش الغراب

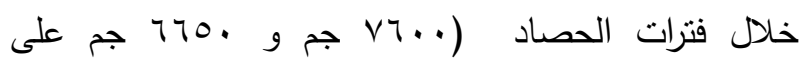

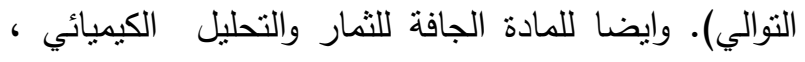

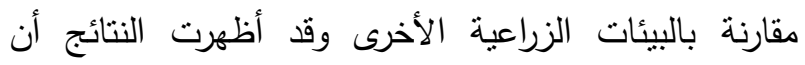

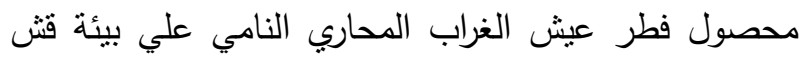

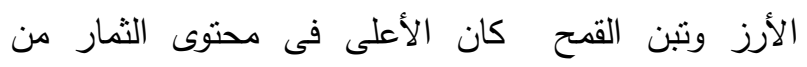

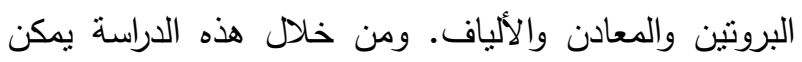
Pleurotus ( التوصية بزراعة فطر عبش الغراب المحارى (ostreatus الناتجة على نسبة عالية من البروتين والفيتامينات والعناصر

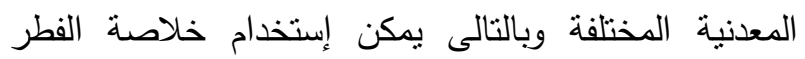

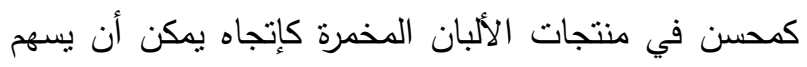
في إنتاج أطعمة وظيفية مبنكرة .
تم إجراء هذه التجربة لدراسة تأثير زراعة فطر عيش

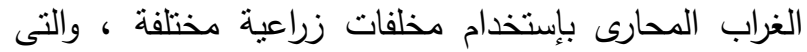

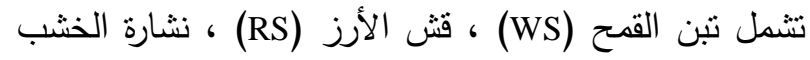

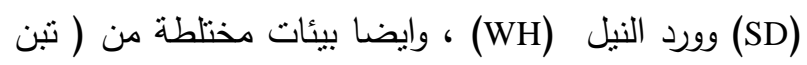

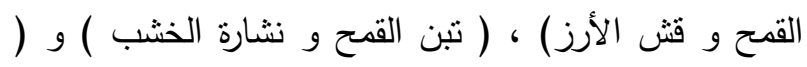

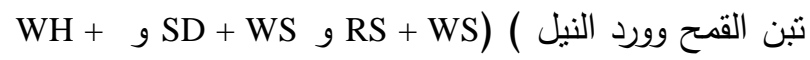

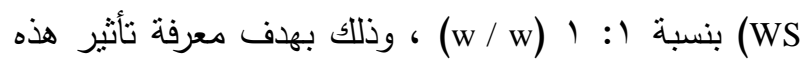
البيئات على نمو وتكوين ثمار المشروم ودرجة قبول الهبول المستهلك لها. وقد أجريت التجارب خلال فصل الثناء فى فترتين ( من سبتمبر إلى ديسمبر ومن يناير إلى أبريل)

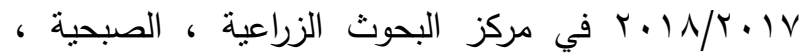

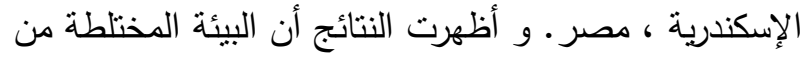
( مش الأرز + ثبن القمح ) وبيئة قش الأرز بمفردها (RS) 